\title{
High Pressure Processing: A Potential Technology for Processing and Preservation of Dairy Foods
}

\author{
Sonaliben L. Parekh ${ }^{1 *}$, K.D. Aparnathi ${ }^{1}$ and V. Sreeja ${ }^{2}$ \\ ${ }^{1}$ Dairy Chemistry Department, ${ }^{2}$ Dairy Microbiology Department, Sheth M.C. College of Dairy \\ Science, Anand Agricultural University, Anand-388110, Gujarat, India \\ *Corresponding author
}

\section{A B S T R A C T}

\begin{tabular}{|c|}
\hline Keywords \\
\hline $\begin{array}{l}\text { High pressure } \\
\text { processing, } \\
\text { Barotolerant, Dairy } \\
\text { foods. }\end{array}$ \\
\hline Article Info \\
\hline $\begin{array}{l}\text { Accepted: } \\
\text { 26 October } 2017 \\
\text { Available Online: } \\
10 \text { December } 2017\end{array}$ \\
\hline
\end{tabular}

Keywords

High pressure

processing,

Barotolerant, Dairy

Accepted:

26 October 2017

10 December 2017
Consumers increasingly demand convenience foods of the highest quality in terms of natural flavor and taste, and which are free from additives and preservatives. This demand has triggered the need for the development of a number of nonthermal approaches to food processing, of which high-pressure technology has proven to be very valuable. Although clear benefits of high pressure processing (HPP) as a non-thermal preservation method have been already established. High pressure thermal (HPT) treatments consist of a combination of high pressure (500$900 \mathrm{MPa})$ and temperature $\left(70-120^{\circ} \mathrm{C}\right)$ over a short holding time. The rapid temperature increase during compression and temperature decrease in the product upon decompression could help to reduce the hardness of thermal effects encountered in conventional thermal technologies.

\section{Introduction}

Traditionally, food is preserved by heat treatment to achieve inactivation of undesirable microbes and give an acceptable shelf life but, it can adversely affect the flavour and nutritional value of some foods. Thus, a number of non-thermal technologies have been studied in recent years; for example, high-pressure (HP) treatment, pulsed electric fields, ionization radiation and ultra-sonication. Of these, HPP probably represents the most promising new possibility for preserving and preparing food products with improved functional and microbiological properties. Theoretically pressure-temperature operational conditions for HPP treatment of foods may range from 100 to $1000 \mathrm{MPa}$ at $-20^{\circ} \mathrm{C}$ to $121^{\circ} \mathrm{C}$, depending on the process and the nature of the food resulting. HPP as a clean label technology has found a growing acceptance in the food industry for producing high-quality foods.

Recent studies have focused on the effects of HPP on health attributes and allergenic potential of foodstuff to develop the next generation of convenience foods (Barba et al., 2015).

\section{History}

Research into the application of HPP for milk preservation began when Hite (1899) 
demonstrated that the shelf life of milk and other food products could be extended by pressure treatment. Unavailability of suitable equipment hampered early applications of HPP. The advances achieved in ceramics and metallurgical industries in the use of HP techniques during the 1970s and 1980s, has led to the possibility of treating food by this method at industrial level. The first commercial HP-treated products (high acid jam) appeared on the market in 1991 in Japan, where HPP is now being used for products such as dairy foods, fruit juices, jams, sauces, rice, cakes and desserts etc. (Tao et al., 2014; Muntean et al., 2016).

\section{Principle}

According to Yordanov and Angellova (2010) a number of physical and chemical changes result from the use of pressure. Physical pressure throughout pressure processing brings about a volume decrease and an increment in temperature and energy. The rationale for the use of HPP is in conformity with the three elements of physical and chemical principles.

LeChatelier's principle: any phenomenon such as chemical reaction, conformational change, stage transition, that is conducted by a decline in volume is improved by pressure. Principle of microscopic ordering: At consistent temperature, an expansion in pressure expands the degrees of ordering of molecules of a particular substance. In this manner pressure and temperature apply opposed forces on molecular structure and chemical reactions.

Isostatic principle: The food items are condensed by even pressure from each angle and after that came back to their unique shape when the pressure is discharged. The items are condensed freely of the item size and geometry in light of the fact that transmission of pressure to the center is most certainly not mass and time dependant therefore the procedure is minimized (Ginsau, 2015; Martínez-Monteagudo and Balasubramaniam, 2016).

\section{Operational technology}

According to Pascal's law, pressure acts instantly, isostatically and homogenously, independently of the size and shape of the material. In HPP of foods, pressures between 100 and 1,000 $\mathrm{MPa}$ are used. This is higher than pressures present in deep sea. In general, the process is batch operated and applied to several liquid and semisolid prepacked foods and food ingredients. HPP is carried out in three steps as follows: an initial period required for reaching the treatment pressure or come-up time, the time of processing at the desired pressure or holding time, and finally, a short time necessary for releasing the pressure or release time. During HHP, the food packed in a flexible packaging material is put in a high pressure cylindrical vessel where it is surrounded by a non-compressible pressure-transmitting medium, usually water. The transmitting medium is pressurized up to the treatment pressure. This pressure is kept constant from a few minutes to multiples of times for $10 \mathrm{~min}$ and immediately release (Dhineshkumar et al., 2016; Neetoo and Chen, 2012).

\section{Effect of HPP on microbes}

\section{Bacteria}

Cell membrane is often considered as the first site of injury in pressure-inactivated bacteria. Indeed, scanning electron microscopy observations show some bud scars on the surface of pressurized cells, suggesting that the cellular wall or membrane may be one of the targets of high pressures. It is known that membrane fluidity decreases when pressure 
increases, implying that micro-organisms with less fluid membranes are more pressure sensitive (Yaldagard et al., 2008). Furthermore, pressure inactivation of bacteria could be associated to modifications of membrane properties, such as the denaturation of membrane bound-proteins or phase transition of the membrane lipid bilayer (Pilavtepe-Ç elik et al., 2008). Gram positive bacteria appear to be more pressure resistant than Gram negative bacteria. The water activity $\left(\mathrm{a}_{\mathrm{w}}\right)$ of the system is also an important factor for the inactivation of bacteria under high pressure (Yordanov and Angelova, 2010). The pressure sensitivity varies with the type of microorganism. Vegetative cells are more sensitive than spores. In addition to the above, inactivation of intracellular enzymes can also cause metabolic inactivation of microbes (Unni et al., 2011).

\section{Yeasts and molds}

In general, yeasts and fungi are more sensitive to high pressure than vegetative bacteria. The inactivation mechanism for yeasts by high pressure is close to the one for bacteria, in that high pressure affects the cell membrane permeability and cellular structures, is responsible for protein denaturation. Indeed, a mild HPP (300 MPa, $15 \mathrm{~min}, 25^{\circ} \mathrm{C}$ ) modifies cell walls and plasma membrane of Saccharomyces cerevisiae, but it seems that the intracellular membrane is the first target in the inactivation process (Black et al., 2007).

\section{Bacterial spores}

Bacterial spores are the environmentally resistant form of some Gram positive bacteria. The high resistance of spores to numerous stresses is mainly due to their particular structure made up of a number of layers. The cortex, which is responsible for the establishment and maintenance of the low water content in the spore core, is probably the main origin of the high pressure resistance of spores. The direct inactivation of spores by high pressure necessitates the application of very high pressures, as high as $827 \mathrm{MPa}$ for $30 \mathrm{~min}$ at $75{ }^{\circ} \mathrm{C}$. In order to kill spores using high pressure, the process is often divided in two steps: one at lower pressures (50 to 300 $\mathrm{MPa}$ ) which initiates the germination process, and one at higher pressures (> $400 \mathrm{MPa}$ ) that inactivates the germinated spores obtained at the end of the first step (Aouadhia et al., 2012; Considine et al., 2008). Rendueles et al., (2011) studied viability loss of foodborne pathogenic spores by HHP with different time, temperature and pressure combinations.

\section{Viruses}

The pressure resistance of viruses varies greatly among virus strains. Viruses are generally classified in two groups: the enveloped and the non-enveloped viruses, according to their structure which is either a membrane enveloped or non-enveloped protein shell and nucleic acid (Olivier et al., 2011). Most of the studies have been conducted on enveloped viruses.

In this case, high pressure can affect three types of interactions: protein-lipid, proteinprotein, and protein-nucleic acid. This later seems to remain intact under high pressure. Non enveloped viruses are usually more pressure resistant than enveloped viruses. Their inactivation is often enhanced when high pressure treatment is applied at subzero temperatures. Under these conditions, proteins can undergo cold denaturation due to a synergistic destabilization of hydrogen bonds and hydration of hydrophobic groups, leading to the loss of quaternary and tertiary structures (Buckow et al., 2009; Kingsley et al., 2007).

\section{Parasites}

Only little information is available on the effect of high hydrostatic pressure on 
parasites. Until now, studies have been conducted on two types of parasites: protozoan parasites and nematodes. Oocysts are the resistant form of protozoan parasites. Oocysts from parasites such as Cryptosporidium parvum or Toxoplasma gondii can be easily inactivated by a pressure comprised between $340 \mathrm{MPa}$ and $550 \mathrm{MPa}$ applied for a short time ( $\leq 3 \mathrm{~min}$ ) (Lindsay et al., 2008; Huang et al., 2014). Studies on nematodes such as Ascarissuum or Anisakis simplex demonstrated that a relatively low pressure $(\approx 200 \mathrm{MPa})$ applied for a short time $(\leq 10 \mathrm{~min})$ is sufficient to inactivate these parasites (Brutti et al., 2010).

\section{Pathogens}

HHP processing can be applied to inactivate pathogens in food, the inactivation is mainly due to cell membrane damage, cell wall rupture and chromosome DNA degradation (Yang et al., 2012; Wang et al., 2013) The synergistic effect of HHP treatment and food additives (FAs) on the inactivation of Salmonella enteritidis was also investigated.

Citric acid, adipic acid, C8-sugarester, C10sugarester, tannin, nisin, wasabi extract, $\varepsilon^{-}$ polylysine, and protamine each showed a strong inactivation effect when administered alone at the $1 \%$ level. In the HHP treatment at $250 \mathrm{MPa}$ for $30 \mathrm{~min}$, the minimum effective concentrations of C8-sugarester, C10sugarester, and protamine were $0.25,0.125$, and $0.06 \%$, respectively (Rendueles et al., 2011; Ogihara et al., 2009).

\section{Use of HPP in dairy foods}

\section{Milk}

Yang et al., (2012) investigated the effect of HHP on Salmonella, Escherichia coli, Shigella and Staphylococcus aureus in raw milk. The results exhibited that $300 \mathrm{Mpa}$ treatment with 30 min duration at $25{ }^{\circ} \mathrm{C}$ was the optimal condition for Salmonella, E. coli, Shigella and S. aureus inactivation. Pandey et al., (2003) was mixed raw milk with a high count of indigenous microflora, with and without inoculated Escherichia coli K-12 (ATCC-29055), subjected to HPP (250-400 $\mathrm{MPa})$ for various holding times (0-80 $\mathrm{min})$ at two temperatures $\left(3\right.$ and $\left.21^{\circ} \mathrm{C}\right)$. They found that higher pressures, longer holding times and lower temperatures resulted in larger destruction of microorganisms, and E. coli was more pressure sensitive than indigenous microflora. Narisawa et al., (2008) investigated the effects of skimmed milk and its protein fractions (casein, whey, globulin, and albumin) on the injury and inactivation of Escherichia coli K-12 by HHP. The protective effect of skimmed milk on HHPmediated inactivation and injury of $E$. coli increased with increases in the skimmed milk concentration. Vachon et al., (2002) studied the inactivation of foodborne pathogens (Listeria monocytogenes [LSD 105-1], Escherichia coli O157:H7 [ATCC 35150], and Salmonella enterica serotype Enteritidis ATCC [13047]) in milk using high pressure ((100, 200, and $300 \mathrm{MPa})$. They found that HP was shown to be very effective for the destruction of pathogens.

\section{Cheese}

Evert-Arriagada et al., (2014) studied the effect of pressure $500 \mathrm{MPa}\left(5 \mathrm{~min}, 16^{\circ} \mathrm{C}\right)$ on starter-free fresh cheeses during cold storage of 21 days. The results showed that pressurised cheeses presented a shelf-life of about 19-21 days when stored at $4{ }^{\circ} \mathrm{C}$, whereas control cheese became unsuitable for consumption on day 7-8. Voigt et al., (2012) observed the ripening of Cheddar cheese manufactured from raw milk (control) and milk HP-treated at $400 \mathrm{MPa}$ or $600 \mathrm{MPa}$ for 10 min at $20^{\circ} \mathrm{C}$. They saw that counts of nonstarter lactic acid bacteria (NSLAB) were 
significantly reduced after HP-treatment of milk at $600 \mathrm{MP}$.

Application of HP substantially reduced the microbial load in Cheddar cheese, with 400 $\mathrm{MPa}$ for $20 \mathrm{~min}$ at $20{ }^{\circ} \mathrm{C}$ being sufficient to reduce the numbers of viable Escherichia coli and Penicillium roqueforti by 7-and 6-logunit cycles, respectively, and to reduce the levels of Staphylococcus aureus by 3-log-unit cycles (Rastogi, 2013). HPT (400-700 MPa) was effective in reducing Listeria monocytogenes in gorgonzola cheese rinds (Carminati et al., 2004) and Turkish white cheese (Evrendilek et al., 2008) without significantly changing its sensory properties. HPT also resulted in total reduction in molds, yeasts, and Enterobacteriaceae counts for the cheese samples produced from raw and pasteurized milk.

HPT (500 MPa, $10 \mathrm{~min}$ ) significantly reduced the level of Listeria monocytogenes in the raw milk and so allowed the production of safer nonthermally processed camembert-type soft cheese (Rastogi, 2013). Arriagada et al., (2012) showed that cheese treated at 300 and $400 \mathrm{MPa}$ and stored at $4{ }^{\circ} \mathrm{C}$ had a shelf life of 14 and 21 days, respectively, compared to 7 days in untreated cheese. Voigt et al., (2010) was studied the effect of HPT (400 MPa, 600 $\mathrm{MPa}$ ) on ripening of mature 42-day-old Irish blue-veined cheese. They found counts of non-starter lactic acid bacteria, lactococci, yeasts, moulds, enterococci and total aerobic bacteria significantly decreased due to HP, with moulds being most sensitive and 600 MPa the most effective treatment.

\section{Yogurt}

Dhineshkumar et al., (2016) and Rastogi, (2013) prepared fruit yogurt by HPT (550 $\mathrm{MPa}$ ) and stored for 4 weeks at refrigerated (4 $\left.{ }^{\circ} \mathrm{C}\right)$ or room $\left(20{ }^{\circ} \mathrm{C}\right)$ temperature. They found that pressure treatment prevented the post acidification of the product and the number of bacteria in the HP-treated yogurt stored at 4 ${ }^{\circ} \mathrm{C}$ was maintained at less than the therapeutic minimum level of $10^{6} \mathrm{CFU} / \mathrm{ml}$. They also saw that no microbial spoilage took place in HPprocessed sample even after 60 days of storage at 4.4 and $25{ }^{\circ} \mathrm{C}$. Moreover, the count of $\mathrm{LAB}$ decreased to $<10 \mathrm{CFU} / \mathrm{ml}$. A further possible application of HPP in yoghurt manufacture is the treatment of the gel following fermentation, to inactivate starter cultures and yeasts and moulds and, thereby, extend the shelf life of the product by prevention of post-acidification. There has also been some commercial interest in selection of barotolerant strains of probiotic bacteria that would survive such treatment selectively (Voigt et al., 2015; Udabage et al., 2010). Two strategies have been used to improve yoghurt quality and preservation by means of HP: yoghurt making from HPtreated milk and pressurisation of yoghurt to inactivate microbiota (Naik et al., 2013; Anema et al., 2005). The application of the high pressure in preliminary treatment of milk used for yoghurt production improved firmness of the curd and limited its syneresis (Udabage et al., 2010; Sfakianakis and Tzia, 2014; Liepa et al., 2016).

\section{Other Dairy Products}

HPP is also used for preparation of channa (Indian cottage cheese) (Sahu, 2010); cream (Trujillo et al., 2002); ice-cream (Huppertz et al., 2011; Chawla et al., 2011). It gives various beneficial effects to the products in terms of sensory, nutritional and quality characteristics.

\section{Current commercial status of HP Processing}

HP processing can be applied to a wide range of foods, including meat-based products (cooked and dry ham, etc.), fish, precooked dishes and fruit, vegetables, and juices. The 
potential of HP in the food processing area has led to its commercialization in many regions, including Asia (Japan, China, and South Korea), North America (United States, Canada, and Mexico), Europe (France, UK, Germany, Spain, Portugal, Italy, etc.), and Australia.

It is estimated that HP food processing represents a market of more than 2 billion US dollars (Tao et al., 2014).

\section{Packaging requirements for HP treatment}

Polymeric materials, including polyethylene terephthalate, polyethylene, polypropylene, ethylene vinyl alcohol copolymer, and their combinations are usually used as the packaging materials for $\mathrm{HP}$ treatment. To improve the barrier properties of the polymeric films, they are occasionally coated with extremely thin layers (a few nanometers thick) of inorganic compounds such as aluminum oxide and silicon oxide, or metalized by the deposition(approximately $0.01 \mathrm{~mm}$ thick) of a thin layer of aluminum (Tao et al., 2014).

\section{Advantages of HPP}

Main benefits of HPP in dairy food processing include inactivation of microorganisms, spores and enzymes, structural modification of proteins and depression of freezing point of water.

Retains natural antimicrobial systems without changing the sensory and nutritional quality of foods and extend shelf life up to 2-3 folds.

Major advantages as significant reduction of heating, this will minimize thermal degradation of food components.

High retention of flavor, colour and nutritional value.
Pressure is transmitted uniformly and instant so that food product retains its shape.

Potential for the design of new products due to the creation of new textures, tastes and functional properties.

Clean technology, flexible system for number of products and operation.

Process time is less dependence of product shape and size.

Reduced requirement of chemical additives, and Increased bioavailability (Huang et al., 2017).

\section{Disadvantages of HPP}

Food must contain water, as the whole phenomenon is based on compression.

Some enzymes are very pressure resistant.

May not inactivate spores so, additional heat treatment is required.

Structurally fragile foods need special attention.

High installation cost (Ginsau, 2015).

\section{HP Regulations}

The USFDA has approved HPP as a nonthermal pasteurization technology that can be used to replace traditional pasteurization in the food industry. USDA (2012) has requirements $E$. coli $\mathrm{O} 157: \mathrm{H} 7$ as the indicator strain for reprocessing, an HPP process that achieves a 5-log E. coli $\mathrm{O} 157: \mathrm{H} 7$ reduction should be sufficient for product produced to ensure microbial safety. The Food and Drug Administration (FDA) in 2009 has approved HPP for production of low acid foods and many food processing industries in USA, 
Japan and European continent have already started using this technique for preparation of various food items (Houska et al., 2006). In Europe, HPP is regarded as a novel technology subject to the Novel Food Regulation. The European Community (EC) recently founded a major multinational research project on HPP to make a real assessment of the potential of high pressure technology for commercialization (Huang at al., 2017). Present status and Indian scenario India is relatively new to the field of high pressure processing. Recently Defence Food Research Laboratory (DFRL), Mysore under the aegis of Defence Research Development Organization (DRDO) has successfully installed the first high pressure processing system in India having a processing capacity of 2 litres and a maximum operating pressure of $900 \mathrm{MPa}$ (Ferstl, 2013).

\section{Future Trends}

Its non-thermal processing nature makes HPP technology a preferred production choice for maintaining food quality. Due to various issues related to HPP, it is required to establishment of relevant laws and regulations. Clearly specified process conditions will ensure microbial safety, product quality, and compliance with food hygienic safety laws and regulations in countries where the manufacturers are located. HPP technology also can be combined with existing trends in the food sector to boost the development of the food industry. For example, high-quality organic food raw materials, fresh local foods with short food miles, and functional health foods are future development trends in the field of HPP (Huang at al., 2017).

The food industry is a sector closely related to the health of consumers, and thus foodprocessing technologies are typically subject to higher hygienic standards than other sectors are. Consumers are willing to purchase a product only if they believe the product is safe. HPP offers opportunities for food manufacturers to develop new foodstuff with extended shelf life, maintains the organoleptic properties and nutritional values. These processing characteristics cannot be achieved using thermal pasteurization technology, and thus the emerging HPP technology better meets the consumer demand for safe, wholesome, new foods containing fewer additives.

\section{References}

Anema, G.G., Lauber, S. and Lee, S.K. 2005. Rheological properties of acid gels prepared from pressure- and transglutaminase-treated skim milk. Food Hydrocolloids, 19:879-887.

Aouadhia, C., Simonin, H., Prévostc, H., de Lamballerie, M., Maaroufi, A. and Mejri, S. 2012. Optimization of pressure-induced germination of Bacillus sporothermodurans spores in water and milk Food Microbiology. 30: 1-7.

Arriagada, K.E., Herrero, M.M.H., Juan, B., Guamis, B. and Trujillo, A. J. 2012. Effect of high pressure on fresh cheese shelf life. J Food Eng. 110:248-253.

Barba F.J., Terefe, N.S., Buckow, R., Knorr, D. and Orlien, V. 2015. New opportunities and perspectives of high pressure treatment to improve health and safety attributes of foods. A review. Food Res. Int., 77: 725-742.

Black, E.P., Kelly, A.L., Fitzgerald, G.F. 2007. The combined effect of high pressure and nisin on inactivation of microorganisms in milk. Innov Food Sci Emerg Technol, 6:286-292.

Brutti, A., Rovere, P., Cavallero, S., D’Amelio, S., Danezi, P., Arcangeli, G., 2010. Inactivation of Anisakis simplex larvae in raw fish using high hydrostatic 
pressure treatments. Food Control., 21: 331-333.

Buckow, R., Weiss, U. and Knorr, D. 2009. Inactivation kinetics of apple polyphenol oxidase in different pressure temperature domains. Innov Food Sci Emerg Technol. 10:441-448

Carminati, D., Gatti, M., Bonvini, B., Neviani, E. and Mucchetti, G. 2004. High-pressure processing of Gorgonzola cheese: influence on Listeria monocytogenes inactivation and on sensory characteristics. J Food Prot., 67:1671-1675.

Chawla, R., Patil, G.R. and Singh, A.K. 2011. High hydrostatic pressure technology in dairy processing: a review. J. Food Sci. Technol., 48(3): 260-268.

Considine, K.M., Kelly, A.L., Fitzgerald, G.F., Hill, L.C. and Sleato, R.D. 2008. High-pressure processing - effects on microbial food safety and food quality. FEMS Microbiol Lett., 281:1-9.

Dhineshkumar, V., Ramasamy, D. and Siddharth, M. 2016. High pressure processing technology in dairy processing: A review. Asian J. Dairy Food Res., 35(2): 87-95.

Evert-Arriagada, K., Hernández-Herrero, M. M., Guamis, B. and Trujillo, A. J. 2014. Commercial application of highpressure processing for increasing starter-free fresh cheese shelf-life. LWT - Food Sci. Technol., 55: 498-505.

Evrendilek, G.A., Koca, N., Harper, J.W. and Balasubramanian, V.M. 2008. Highpressure processing of Turkish white cheese for microbial inactivation. $J$ Food Prot., 71:102-108.

Ferstl, C. 2013. High pressure processing insights on technology and regulatory requirements. Food for Thought Topical Insights from the National Food Lab White Paper Series Vol. 10.

Ginsau, M.A. 2015. High pressure processing: A novel food preservation technique. $J$.
Environ. Sci., Toxicol.Food Technol., 9(5): 109-113.

Hite, B.H. 1899. The effect of pressure in the preservation of milk, Bull. West Virginia Univ. Agr. Expt. Sta., Morgantown. 58: 15-35.

Houska, M., Strohalm, Jan, Kocurova, K., Totusek, Jiri, Lefnerova, D., Triska, Jan, Vrchotova, N., Fiedlerova, V., Holasova, M., Gabrovska, D. and Paulickova, I. 2006. High pressure and foods - fruit/vegetable juices. J Food Eng., 77: 386-398.

Huang, H.W., Lung, H.M., Yang, B.B. and Wang, C.Y. 2014. Responses of microorganisms to high hydrostatic pressure processing. Food Control., 40: 250-259.

Huang, H.W., Wu, S.J., Lu, J.K., Shyu, Y.T. and Wang, C.Y. 2017. Current status and future trends of high-pressure processing in food industry. Food Contro, 172: 1-8.

Huppertz, T., Smiddy, M.A., Kelly, A.L. and Goff, H.D. 2011. Effect of high pressure treatmentof mix on ice cream manufacture. Int Dairy J., 21: 718-727.

Kingsley, D.H., Hoover, D.G., Papfragkou, E., and Richards, G.P. 2007. Inactivation of hepatitis $\mathrm{A}$ virus and a calicivirus by high hydrostatic pressure. Journal of Food Protection, 65: 16051609.

Liepa, M., Zagorska, J. and Galoburda, R. 2016. High-pressure processing as novel technology in dairy industry: A review. Res. Rural Develop., 1: 76-83.

Lindsay, D.S., Collins, M.V., Holliman, D., Flick, G.J. and Dubey, J.P. 2008. Effects of high-pressure processing on Toxoplasma gondii tissue cysts in ground pork. J Parasitol., 92:195-196

Martínez-Monteagudo, S.I. and Balasubramaniam, V.M. 2016. Fundamentals and applications of highpressure processing technology. In 
"High Pressure Processing of Food: Principles, Technology and Applications" (V.M. Balasubramaniam, G.V. Barbosa-Canovas and H.L.M. Lelieveld Eds.). Springer-Verlag, New York. PP 3-18.

Muntean, M.V., Marian, O., Barbieru, V., Cătunescu, G.M., Ranta, O., Drocas, I. and Terhes, S. 2016. High pressure processing in food industry Characteristics and applications. Agric. Agril. Sci. Procedia., 10: 377-383.

Naik, L., Sharma, R., Rajput, Y.S. and Gaare, M. 2013. Application of high pressure processing technology for dairy food preservation - future perspective: A review. J. Anim. Prod. Adv., 3(8): 232241

Narisawa, N., Furukawa, S., Kawarai, T., Ohishi, K., Kanda, S., Kimijima, K., Negishi, S., Ogihara, H., and Yamasaki, M. 2008. Effect of skimmed milk and its fractions on the inactivation of Escherichia coli K12 by high hydrostatic pressure treatment. Int. J. Food Microbiol., 124: 103-107.

Neetoo, H. and Chen, H. 2012. Application of high hydrostatic pressure technology for processing and preservation of foods. In "Progress in Food Preservation", First Edition (R. Bhat, A.K. Alias and G. Paliyath Eds.). John Wiley \&andSons, Ltd., The Atrium, Sourthen Gate, Chichester, West Sussex, PO198SQ, UK. P247-276.

Ogihara, H., Yatuzuka, M., Horie, N., Furukawa, S. and Yamasak, M. 2009. Synergistic effect of high hydrostatic pressure treatment and food additives on the inactivation of Salmonella enteritidis. Food Control., 20: 963-966.

Olivier, S.A., Bull, M.K., Stone, G., van Diepenbeek, R.J., Kormelink, F., Jacops, L., Chapman, B. 2011. Strong and consistently synergistic inactivation of spores of spoilage-associated
Bacillus and Geobacillus spp. by high pressure and heat compared with inactivation by heat alone. Applied and Enviro. Microbiol. 77:2317-2324.

Pandey, P.K., Ramaswamy, H.S., Idziak, E. 2003. High pressure destruction kinetics of indigenous microflora and Escherichia coli in raw milk at two temperatures. J. Food Process Engg., 26: $265-283$.

Pilavtepe-C, elik, M., Balaban, M.O., Alpas, H., Yousef, A.E. 2008. Image analysis based quantification of bacterial volume change with high hydrostatic pressure. J. Food Sci., 73:423-429.

Rastogi, N.K. 2013. High-pressure processing of dairy products. In "Recent Developments in High Pressure Processing of Foods". Springer Briefs in Food, Health, and Nutrition (R.W. Hartel and J.P. Clark Eds.) PP 51-64.

Rendueles, E., Omer, M.K., Alvseike, O., Alonso-Calleja, C., Capita, R. and Prieto, M. 2011. Microbiological food safety assessment of high hydrostatic pressure processing: A review. LWT Food Sci. Technol., 44: 1251-1260.

Sahu, J.K. 2010. Coagulation kinetics of high pressure treated acidified milk gel for preparation chhana (an Indian soft cottage cheese). Int. J. Food Prop., 13:1054-1065.

Sfakianakis, P., and Tzia, C. 2014. Conventional and Innovative Processing of Milk for Yogurt Manufacture; Development of Texture and Flavor: A Review. Foods, 3(1), 176-193. DOI: 10.3390/foods 3010176.

Tao, Y., Sun, D.W., Hogan, E. and Kelly, A.L. 2014. High pressure processing of foods: An overview. In "Emerging Technologies for Food Processing" (D.W. Sun Ed.), Second Edition. Academic Press (an imprint of Elsevier), 32 Jamestown Road, London NW1 7BY, UK. PP 3-24. 
Trujillo, A.J., Capellas, M., Saldo, J., Gervilla, R. and Guamis, B. 2002. Applications of high-hydrostatic pressure on milk and dairy products: a review. Innov Food Sci Emerg Technol., 3:295-307

Udabage, P., Augustin, M.A. and Versteeg, C. 2010. Properties of low-fat stirred yoghurts made from high-pressureprocessed skim milk. Innov Food Sci Emerg Technol, 11:32-38.

United States Department of Agriculture (USDA). 2012. High pressure processing (HPP) and inspection program personnel (IPP) verification responsibilities. FSIS Directive 6120.1.

Unni, L.E, Chauhan, O.P., Raju, P.S. and Bawa, A.S. 2011. High pressure processing of foods: Present status and future strategies. Int. J. Food Ferment. Technol., 1(1): 49-62.

Vachon, J.F., Kheadr, E.E., Giasson, J., Paquin, P. and Fliss, I. 2002. Inactivation of foodborne pathogens in milk using dynamic high pressure. $J$. Food Prot., 65:345-352.

Voigt, D.D., Chevalier, F., Donaghy, J.A., Patterson, M.F., Qian, M.C., Kelly, A.L. 2012. Effect of high-pressure treatment of milk for cheese manufacture on proteolysis, lipolysis, texture and functionality of Cheddar cheese during ripening. Innovative Food Sci. Emerging Technologies., 13: 23-30.

Voigt, D.D., Chevalier, F., Qian, M.C. and Kelly, A.L. 2010. Effect of high- pressure treatment on microbiology, proteolysis, lipolysis and levels of flavour compounds in mature blueveined cheese. Innovative Food Sci. Emerging Technologies, 11: 68-77.

Voigt, D.D., Kelly, A.L. and Huppertz, T. 2015. High-pressure processing of milk and dairy products. In "Emerging Dairy Processing Technologies Opportunities for the Dairy Industry" (N. Datta and P.M. Tomasula Eds.). 9600 Garsington Road, Oxford, OX4 2DQ, UK. PP 71-92.

Wang, C.Y., Huang, H.W., Hsu, C.P., Shyu, Y.T. and Yang, B.B. 2013. Inactivation and morphological damage of Vibrio parahaemolyticus treated with high hydrostatic pressure. Food Control., 32: 348-353.

Yaldagard, M., Mortazavi, S.A., Tabatabaie, F. 2008. The principles of ultra-high pressure technology and its application in food processing/preservation: a review of microbiological and quality aspects. African J Biotechnol. 7, 27392767.

Yang, B.,Shi, Y.,Xia, X.,Xi, M.,Wang, X.,Ji, B. and Meng, J. 2012. Inactivation of foodborne pathogens in raw milk using high hydrostatic pressure. Food Control, 28: 273-278.

Yordanov, D.G. and Angelova, G.V. 2010. High pressure processing for foods preserving. Biotechnol. Biotechnol. Eq, 24(3): $\quad$ 1940-1945. DOI: 10.2478/v10133-010-0057-8.

\section{How to cite this article:}

Sonaliben, L. Parekh, K.D. Aparnathi and Sreeja, V. 2017. High Pressure Processing: A Potential Technology for Processing and Preservation of Dairy Foods. Int.J.Curr.Microbiol.App.Sci. 6(12): 3526-3535. doi: https://doi.org/10.20546/ijcmas.2017.612.410 